\title{
Correction: Global analysis of host response to induction of a latent bacteriophage
}

\author{
Robin E Osterhout ${ }^{*}$, Israel A Figueroa, Jay D Keasling and Adam P Arkin
}

\section{Correction}

After the publication of this work [1], we became aware that the legends for Figures 2, 3 and 4 were not in the correct order.

The legends should be as follows:

Figure 2: Escherichia coli lambda lysogen DNA and average transcript levels after treatment with $10 \mathrm{~J} / \mathrm{m} 2$ UV light. The x-axis is the position of genes on the $E$. coli chromosome. The E. coli origin is at the 0 position on the $\mathrm{x}$-axis. The lambda integration site $a t t B$ is indicated by the vertical line. The $y$-axis is the log ratio of treated to untreated cells. A). Average transcription (100 bins) along the $E$. coli chromosome at 20, 40, 60 minutes after exposure to UV light. B). Ratio of DNA 60 minutes after treatment with UV light relative to DNA of untreated cells.

Figure 3: Functional categorization of E. coli genes during lambda phage induction. Histograms count number of genes significantly up-regulated (black) or downregulated (grey) at each time interval. Genes were grouped according to the NCBI COG classification scheme [49]. Categories with an $\left(^{*}\right)$ were enriched in down-regulated genes (Fisher exact test, false discovery rate $<0.05$ ): carbon catabolism, cell processes, cell structure, central metabolism energy metabolism, and transport.

Figure 4: A) Diagram of the linear (integrated) lambda phage genome, color-coded by lifecycle stage (blue $=$ lysogenic, yellow = early lytic, red = late lytic). B) (wild type phage) and C) (Lambda-P27): gene expression ratios during prophage induction are shown relative to an untreated "mock induction" control and $\log _{2}$ transformed. Genes arranged by order on the lambda genome.

Received: 5 August 2013 Accepted: 5 August 2013

Published: 6 August 2013

\footnotetext{
* Correspondence: reosterhout@berkeley.edu

Department of Bioengineering and Howard Hughes Medical Institute,

University of California at Berkeley, Berkeley, CA 94720, USA
}

Reference

1. Osterhout RE, Figueroa IA, Keasling JD, Arkin AP: Global analysis of host response to induction of a latent bacteriophage. BMC Microbiol 2007, 7:82.

doi:10.1186/1471-2180-13-183

Cite this article as: Osterhout et al.: Correction: Global analysis of host response to induction of a latent bacteriophage. BMC Microbiology 2013 13:183.

\section{Submit your next manuscript to BioMed Central and take full advantage of:}

- Convenient online submission

- Thorough peer review

- No space constraints or color figure charges

- Immediate publication on acceptance

- Inclusion in PubMed, CAS, Scopus and Google Scholar

- Research which is freely available for redistribution

Submit your manuscript at

www.biomedcentral.com/submit

( Biomed Central

\section{() Biomed Central}

(c) 2013 Osterhout et al.; licensee BioMed Central Ltd. This is an Open Access article distributed under the terms of the Creative Commons Attribution License (http://creativecommons.org/licenses/by/2.0), which permits unrestricted use, distribution, and reproduction in any medium, provided the original work is properly cited. 